\title{
Simultaneous determination of anionic and nonionic surfactants in commercial laundry wastewater and anaerobic fluidized bed reactor effluent by online column-switching liquid chromatography/tandem mass spectrometry
}

\author{
Fabrício Motteran ${ }^{\mathrm{a}, *}$, Paulo C.F. Lima Gomes ${ }^{\mathrm{b}}$, Edson L. Silva ${ }^{\mathrm{c}}$, Maria Bernadete A. Varesche ${ }^{\mathrm{a}}$

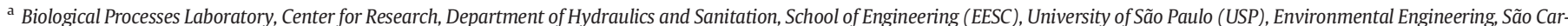 \\ los, Bloco 4-F, Av. João Dagnone, 1100 Santa Angelina, 13563-120 São Carlos, São Paulo, Brazil \\ ${ }^{\mathrm{b}}$ Department of Analytical Chemistry, Institute of Chemistry, Sao Paulo State University - UNESP, P.O. Box 355, 14800-060 Araraquara, São Paulo, Brazil \\ ' Department of Chemical Engineering, Federal University of São Carlos, Rod. Washington Luiz, Km 235, SP 310, 13565-905 São Carlos, SP, Brazil
}

\section{H I G H L I G H T S}

- SPE-online method in LC-MS/MS system is efficient to determine LAS and LAE surfactant.

- The anaerobic fluidized bed reactor is efficiently in laundry wastewater treatment.

- The FBR afforded to identify the breaking of LAS homologs in anaerobic condition.
GR A P H I C A L A B S T R A C T

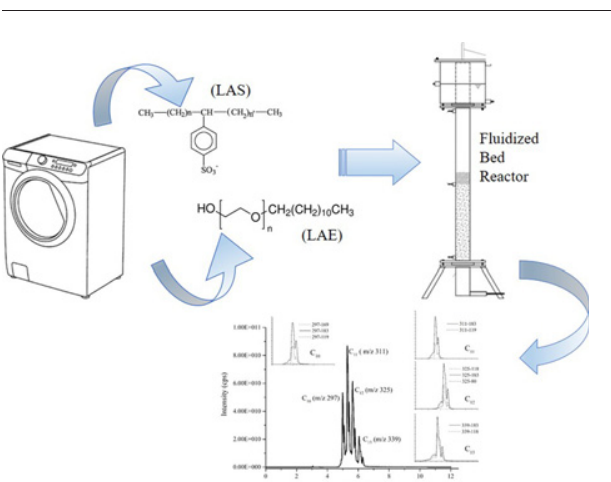

\begin{abstract}
A B S T R A C T
This study presents a new method developed for the simultaneous determination of anionic surfactant (linear alkylbenzene sulfonate - LAS, 4 homologs) and nonionic surfactant (linear alcohol ethoxylate - LAE) in commercial laundry wastewater. The surfactants were identified and quantified using online column-switching solidphase extraction (SPE) coupled with liquid chromatography/tandem mass spectrometry (LC-MS/MS). Ten and three transitions $(\mathrm{m} / \mathrm{z})$ were identified for LAS and LAE, respectively. The detection and quantification limits were 75 and $200 \mu \mathrm{g} / \mathrm{L}$ for LAS, respectively, and $75 \mu \mathrm{g} / \mathrm{L}$ for LAE. This method was applied to the determination of the surfactants in the influent and effluent of an anaerobic fluidized bed reactor that was used for the treatment of commercial laundry wastewater. After 480 days of operation with a hydraulic retention time (HRT) of $18 \mathrm{~h}$, the removal of $45.9 \pm 5.6 \%$ LAS and $99.2 \pm 4.3 \%$ LAE from an influent with surfactant concentrations of $26.1 \pm 12.9 \mathrm{mg} / \mathrm{L}$ and $23.8 \pm 6.8 \mathrm{mg} / \mathrm{L}$, respectively, was obtained. Under these conditions, the breakage of longer-chain LAS homologs with the release of carbon units was observed with an increase in the number of shorter homolog chains. This SPE online sample treatment method is simple, fast and effective for the analysis of both surfactants. This technique is pioneering in its simultaneous measurement of two surfactant categories in anaerobic fluidized bed reactors.
\end{abstract}

(c) 2016 Elsevier B.V. All rights reserved.

\footnotetext{
* Corresponding author.

E-mail address: fabricio.moterani@gmail.com (F. Motteran).
} 


\section{Introduction}

The pollution of ecosystems, including waterways and sediments, usually occurs through the disposal of organic matter and chemical compounds (Boll et al., 2002). Among these chemicals, surfactants and polycyclic aromatic hydrocarbons are organic pollutants that are most commonly detected and that accumulate in freshwater sediments (Boll et al., 2002; Cowan-Ellsberry et al., 2013). Linear alkylbenzene sulfonate (LAS) and linear alcohol ethoxylate (LAE) are two types of surfactants present in different aquatic ecosystems (Comber et al., 2006).

Surfactants are produced in large quantities and used every day in various industrial and domestic activities. Thus, they have a high contribution to the pollution of water-collecting systems and water bodies, where these compounds and their degradation byproducts can have unwanted effects on aquatic life and microbial ecosystems.

Synthetic surfactants are the most widely used among organic compounds produced worldwide and have great economic importance in the production of detergents and personal care and pharmaceutical products (Thiele, 2005; Ying, 2006). According to the European Committee of Organic Surfactants and their Intermediates, approximately 945,000 tons of anionic surfactants and 784,000 tons of nonionic surfactants (ethoxylate) were sold in Europe in 2014 alone, representing approximately $90 \%$ of the total European production of surfactants (De Cooman, 2014).

Linear alkylbenzene sulfonate (LAS) is the most important anionic synthetic surfactant (derived from petroleum) with high global production. This surfactant is mainly used in industry as well as in household and laundry detergents. Due to its high usage and production, it is discharged into wastewater in large quantities (Tolls et al., 1999). LAS is a mixture of isomers and homologs with alkyl chain lengths ranging from 10 to 16 carbon atoms. Attached to the carbon chain there is a benzene radical (phenyl) linked to a sulfonated molecule $\left(\mathrm{SO}_{3}^{-}\right.$) (Larson et al., 1995).

Linear alcohol ethoxylate (LAE) is a nonionic surfactant derived from coconut oil. This surfactant is a mixture of alkyl chains containing 12 to 14 carbon atoms that are bonded through an ether linkage of ethylene oxide units (average of 10 units) (Motteran et al., 2014). These nonionic surfactants are widely used in household and industrial cleaning products, such as detergents, emulsifiers, dispersing agents, and humectants in the paper processing and textile industries (HERA, 2009).

In the wastewater treatment process containing surfactants, approximately $50 \%$ of the LAS load is removed by biodegradation, a fraction (25\%) is adsorbed onto suspended solids, and another $25 \%$ is adsorbed on the solids dissolved in organic matter in the liquid (Brunner et al., 1988; Prats et al., 1997; Berna et al., 2007). Depending on the applied system and process, $81 \%$ to $99.9 \%$ of the surfactants are removed from wastewater treatment systems (Morrall et al., 2006). However, up to $872 \mu \mathrm{g} / \mathrm{L}$ of LAS and $0.24-3.0 \mu \mathrm{g} / \mathrm{L}$ of alcohol ethoxylate in the effluents from sewage treatment plants can still be detected (Dyer et al., 2006).

Chromatographic analytical separation techniques, such as gas chromatography (GC), high performance liquid chromatography (HPLC), mass spectrometry (MS), and their combinations, are increasingly being used in analytical chemistry for the quantitative and qualitative analysis of complex environmental samples (Cassiano et al., 2009; Ribani et al., 2004).

Several methods for the analysis of the surfactant concentration in water and wastewater samples from sewage treatment systems have been reported (Lara-Martín et al., 2012, 2006; Rico-Rico et al., 2009; Riu et al., 2001). The most selective methods such as GC or HPLC with ultraviolet (UV) or fluorescence detection, have been used. However, GC methods are limited by the low volatility of the surfactant molecules with higher molecular weight (Evans et al., 1997). The use of HPLC with UV or fluorescence detector requires derivatization techniques and methodologies for the alcohol ethoxylates (AE) as they do not contain chromophore groups, in contrast to the LAS surfactant (Dubey et al., 1995).
The influents of domestic and industrial sewage treatment systems are complex mixtures of liquids and suspended solids and contain several analytes at very low concentrations. Liquid chromatography coupled to tandem mass spectrometry (LC-MS/MS) is a very sensitive and selective detection method and is extremely valuable for determining low concentrations of contaminants (ng/L to $\mu \mathrm{g} / \mathrm{L}$ ), including these surfactants (Evans et al., 1997).

Methods employing solid phase extraction (SPE) have been used extensively for the analysis of dissolved organic compounds in the complex matrices of environmental samples (Mayer et al., 2000; ter Laak et al., 2006), but the conventional form of these methods (off-line) features many steps that require long processing times (Pan et al., 2014). Online settings are available to overcome these limitations and require unique equipment, valve arrangements and peristaltic pumps.

The aim of this study was to develop and validate a method using a column-switching SPE online system in conjunction with liquid chromatography (LC) coupled to tandem mass spectrometry (SPE online LC-MS/MS) to simultaneously analyze two distinct categories of surfactants, linear alkylbenzene sulfonate (LAS) anionic surfactant and linear alcohol ethoxylate (LAE) nonionic surfactant found in the matrix of commercial laundry wastewater and the influent and effluent of an anaerobic fluidized bed reactor.

The advantages of this new technique are its minimal handling and the pretreatment of complex samples from laundry wastewater and bioreactor effluents. Furthermore, the sample preparation step and chromatographic analysis lasted only 22 min being possible to analyze both surfactants under investigation. This analysis was performed using a conventional LC system containing a column switch with sixport valves, eliminating the need for a unique system for this analysis.

\section{Materials and methods}

\subsection{Chemicals and reagents}

For all solutions, ultrapure water supplied by the Milli-Q Plus Ultra System (Billerica, MA) was used. All reagents used in this study were of high-purity grade ( $>98 \%$ ). The surfactants used in the method development were linear alkylbenzene sulfonate (LAS) and linear alcohol ethoxylate (LAE), both from Sigma-Aldrich ${ }^{\circledR}$ (St. Louis, MO).

LAS is an anionic surfactant composed of a mixture of isomers and a homolog series with linear alkyl chain lengths varying from $C_{10}$ to $C_{16}$, with a predominance of $C_{10}$ to $C_{13}$. LAS has a molar mass of $348.48 \mathrm{~g} / \mathrm{mol}$ (Fig. 1).

The nonionic surfactant used in this study, both as the standard and for the reactor feeding, was the linear alcohol ethoxylate known as LAE, with the commercial name Genapol ${ }^{\circledR}$ C-100. This surfactant is derived from coconut oil, is a mixture of $C_{12}$ and $C_{14}$ alkyl chains with an average of 10 ethoxy units, and has molar mass of $627 \mathrm{~g} / \mathrm{mol}$. Its chemical structure is presented in Fig. 2.

Stock solutions $(6 \mathrm{~g} / \mathrm{L})$ of LAS and LAE, separate and mixed, were prepared in ultrapure water. Analytical solutions (LC-MS/MS) were prepared (diluted from the stock solutions) in water and in a similar matrix composition to that of the reactor influent (lab-made sewage) containing yeast extract, sodium bicarbonate, and a salts solution (Table 1 ). The

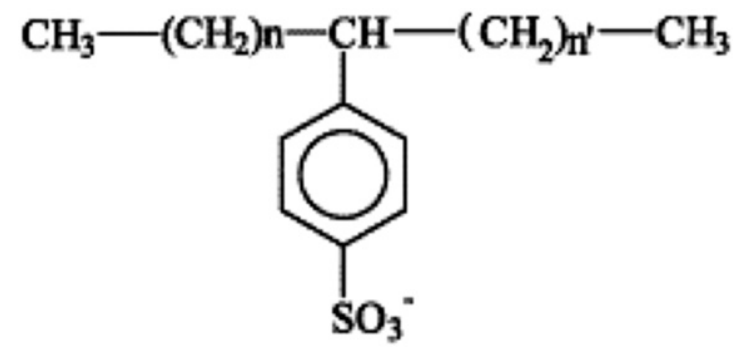

Fig. 1. Molecular structure of linear alkylbenzene sulfonate (LAS), $n+n^{\prime}=7$ a 11 . 


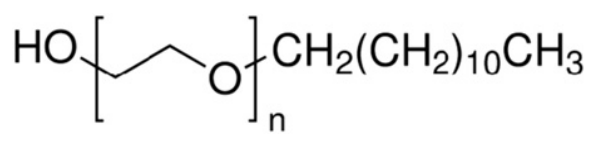

Fig. 2. Molecular structure of the nonionic surfactant LAE, Genapol ${ }^{\circledR}$ C-100 from SigmaAldrich ${ }^{\circledR}$, where $\mathrm{n}$ is the number of ethoxy units.

sample preparation of both standards as the influent and effluent of the anaerobic fluidized bed reactor consisted only of filtration (membrane with $0.22 \mu \mathrm{m}$ pore size); the addition of any chemical or derivatization procedure was not necessary.

\subsection{Instrumentation}

\subsubsection{Analytical separation system}

The analytical separation was performed using liquid chromatography (LC) Agilent 1200 series (Palo Alto, CA) containing two binary pumps, an autosampler ALS 1200 with an injection capacity of $0.1 \mu \mathrm{L}$ to $100 \mu \mathrm{L}$, a thermostatic chamber for analytical column (TCC) 1200 , and a diode array detector (DAD) Infinity 1290. An additional binary LC pump, model LC-10 AVP from Shimadzu (Kyoto, Japan), was used for sample loading for the column-switching and the SPE online system.

\subsubsection{Liquid chromatography-tandem mass spectrometry system}

A hybrid quadrupole-linear ion trap mass spectrometer, QTRAP 5500 from AB SCIEX (Foster, CA), with a turbo ion spray source coupled to the LC (liquid chromatography) system was used.

The ion source parameters for LAS and LAE were optimized by flow injection analysis as follows: a curtain gas (CUR) of $10 \mathrm{~V}$, a nitrogen collision gas (CAD) medium, a source temperature (TEM) of $650^{\circ} \mathrm{C}$, an ion spray voltage of $4500 \mathrm{~V}$ and a pressure of $45 \mathrm{psi}$ for both ion source gases GS1 and GS2.

The compound-dependent MS/MS parameters (declustering potential-DP, collision energy-CE and collision cell exit potential-CXP) were optimized by a direct infusion solution of a surfactant mixture (LAS and $\mathrm{LAE}$ ) at a concentration of $100 \mu \mathrm{g} / \mathrm{L}$. A total of 10 transitions for the anionic surfactant linear alkylbenzene sulfonate (LAS) in ESI(-) mode and 3 transitions for the nonionic surfactant linear alcohol ethoxylate (LAE) in $\mathrm{ESI}(+)$ mode (Table 2 ) were found.

The entrance potential-EP was set at $10 \mathrm{~V}$. The QTRAP was operated in negative mode (ESI -) for the anionic surfactant LAS and in positive mode $(E S I+)$ for the nonionic surfactant LAE; both surfactants used selected reaction monitoring (SRM) with a dwell-time of $20 \mathrm{~ms}$ between each SRM monitored. Three different SRM transitions for each compound were used. The resolution at the first quadrupole and the linear ion trap (Q1 and Q3) was set to unitary 1. Analyst ${ }^{\circledR}$ 1.5.1 software from AB Sciex ${ }^{\circledR}$ was used for analysis, method optimization and LC$\mathrm{MS} / \mathrm{MS}$ operation. The analyzed transitions and collision energies are shown in Table 2.

The chromatographic run lasted $22 \mathrm{~min}$ at a flow rate of $600 \mu \mathrm{L} / \mathrm{min}$, and the LC column temperature was $20 \pm 1{ }^{\circ} \mathrm{C}$. The mobile phase composition used during the chromatographic run that preceded analysis by mass spectrometry was as follows: Eluent A - triethylamine $(5 \mathrm{mM})$, formic acid $(5 \mathrm{mM})$ and ammonium acetate $(10 \mathrm{mM})$; Eluent $\mathrm{B}$ -

\section{Table 1}

Composition of the lab-made sewage: fluidized bed reactor influent and matrix for the analytical chromatography method.

\begin{tabular}{ll}
\hline Nutrients & Volume in $50 \mathrm{~L}$ \\
\hline Yeast extract $(\mathrm{g})$ & 25 \\
Sodium bicarbonate $(\mathrm{g})$ & 20 \\
Ethanol $(\mathrm{mL})$ & 6.3 \\
Salts solution $(\mathrm{mL})$ & 50 \\
$\left(50 \mathrm{~g} / \mathrm{L} \mathrm{NaCl} ; 1.4 \mathrm{~g} / \mathrm{L} \mathrm{MgCl} \cdot 6 \mathrm{H}_{2} \mathrm{O} ; 0.9 \mathrm{~g} / \mathrm{L} \mathrm{CaCl} \cdot 2 \mathrm{H}_{2} \mathrm{O}\right)$ &
\end{tabular}

Source: Duarte et al. (2008), modified by Motteran et al. (2014).

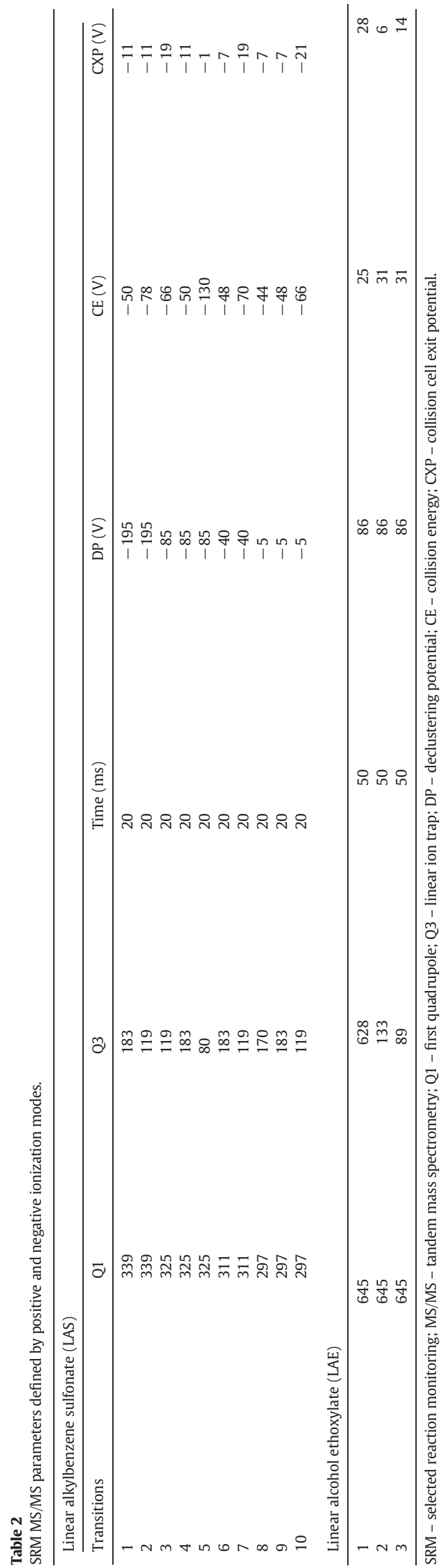


Table 3

Mobile phase gradient program for LC-MS/MS.

\begin{tabular}{lll}
\hline Gradient elution program & & \\
\hline Total time (min) & $\begin{array}{l}\text { Eluent A } \\
(\%)\end{array}$ & $\begin{array}{l}\text { Eluent B } \\
(\%)\end{array}$ \\
\hline 1.00 & 50 & 50 \\
3.10 & 50 & 50 \\
3.50 & 25 & 75 \\
8.00 & 25 & 75 \\
9.00 & 10 & 90 \\
13.00 & 5 & 95 \\
20.00 & 5 & 95 \\
20.10 & 50 & 50 \\
22.00 & 50 & 50 \\
\hline
\end{tabular}

LC-MS/MS - liquid chromatography coupled to tandem mass spectrometry.

acetonitrile containing $0.1 \%$ formic acid ( $\mathrm{v} / \mathrm{v})$. The mobile phase (eluent) gradient program is shown in Table 3.

\subsubsection{Column-switching system}

A column-switching setup was used in the sample preparation procedure. This system consisted of the following two LC pumps: pump A for sample loading and pump B for gradient elution. Column-switching was performed using a two-position, six-port valve from Rheodyne (Rohnert Park, CA).

The online sample preparation applied in the system was performed using an Oasis HLB SPE column cartridge $(2.1 \times 20 \mathrm{~mm}, 25 \mu \mathrm{m})$ containing a hydrophilic-lipophilic balance polymer acquired from Waters (Milford, MA). The backflush mode was used in column-switching, as described by Lima Gomes et al. (2015).

Thus, the sample was introduced into the SPE column in an aqueous phase via pump A. At the same time, the C18 column (Agilent Poroshell, $50 \times 3.0 \mathrm{~mm} \times 2.7 \mu \mathrm{m}$ ) was conditioned with the mobile phase via pump B. After $3 \mathrm{~min}$, the column-switching valve was switched from position $A$ to position $B$, allowing the pre-concentrated analytes in the SPE column to be eluted into the analytical column, followed by the detector (MS/MS). The backflush elution mode resulted in better analyte focalization on the analytical column.

\subsection{Validation procedure}

\subsubsection{Linearity}

Linearity was evaluated from the calibration curve obtained using spiked lab-made sewage samples. Analysis of variance (ANOVA) was applied to verify the linearity and lack of fit to each compound transition monitored. Triplicate assays were performed at eight different concentration levels $(75 \mu \mathrm{g} / \mathrm{L}, 150 \mu \mathrm{g} / \mathrm{L}, 350 \mu \mathrm{g} / \mathrm{L}, 500 \mu \mathrm{g} / \mathrm{L}, 1000 \mu \mathrm{g} / \mathrm{L}$, $2000 \mu \mathrm{g} / \mathrm{L}, 3000 \mu \mathrm{g} / \mathrm{L}$, and $6000 \mu \mathrm{g} / \mathrm{L})$.

\subsubsection{Detection and quantification limits}

The minimum detection limit (MDL) was determined at a signal/ noise ratio of 3:1, comparing the measurement signals of the surfactant samples at low concentrations with respect to the matrix signal (labmade sewage without surfactants) (ICH, 2005). The minimum quantification limit (MQL) was determined at a signal/noise ratio of 10:1, which provided an accuracy of $<20 \%$ (ICH, 2005).

\subsubsection{Precision}

Precision was evaluated from the relative standard deviation (RSD\%) at concentrations of $75 \mu \mathrm{g} / \mathrm{L}$ to $6000 \mu \mathrm{g} / \mathrm{L}$ for all transitions (339-183, 339-119, 325-119, 325-183, 325-80, 311-183, 311-119, 297-170, $297-$ $183,297-119,645-628,645-133$, and 645-89) with intra-day replicates.

\subsection{Anaerobic fluidized bed reactor}

An anaerobic fluidized bed reactor (FBR) with increased scale was used in this study for the treatment of commercial laundry wastewater containing the surfactants LAS and LAE and was built with acrylic materials $(10 \mathrm{~cm}$ in diameter and $2.93 \mathrm{~m}$ high). The total reaction volume was $18.8 \mathrm{~L}$. A distributor was installed at the bottom portion of the reactor to ensure flow uniformity within the system, and on top, a phase separator was installed to prevent solid particles from exiting the reactor and to ensure effluent output.

A hydraulic retention time (HRT) of $18 \pm 2 \mathrm{~h}$ (feeding flow rate of $900 \mathrm{~mL} / \mathrm{h}$ ) was used. For the biomass immobilization, the FBR was filled with expanded clay with an average diameter of $1.55 \mathrm{~mm}$ as support material. The minimum fluidization velocity applied to the reactor was $0.62 \mathrm{~cm} / \mathrm{s}$, with a flow rate of $229 \mathrm{~L} / \mathrm{h}$ (30\% higher than the minimum fluidization velocity).

Influent (lab-made sewage with commercial laundry wastewater) and reactor effluent samples were analyzed two times per week. The chemical oxygen demand (COD) and $\mathrm{pH}$ were analyzed according to APHA-AWWA-WEF (2005). The alkalinity was determined using the methodology developed by Dilallo and Albertson (1961) and modified by Ripley et al. (1986).

The fluidized bed reactor was inoculated with anaerobic sludge from the upflow anaerobic sludge blanket (UASB) of a poultry slaughterhouse wastewater treatment facility located in the city of Tiete (São Paulo/Brazil).

The anaerobic fluidized bed reactor influent was prepared by mixing the compounds described in Table 1 with commercial laundry wastewater, with proportions of LAS and LAE that corresponded to the concentrations in each operational phase. The commercial laundry wastewater was diluted or not depending on the concentration of surfactant present in the raw wastewater to obtain similar surfactant concentrations in each phase, since there is a high variation of surfactants in laundry wastewater (Braga and Varesche, 2014). The lab-made sewage was the major component of the reactor influent mixture compared with commercial laundry wastewater.

The FBR was operated under the following conditions: (1) inoculation of the support material with the biomass for 17 days; (2) adaptation of the biomass to the lab-made sewage without added laundry wastewater for 94 days; (3) Phase I, feeding of the reactor with labmade sewage containing commercial laundry wastewater containing LAS $(8.7 \pm 5.2 \mathrm{mg} / \mathrm{L})$ and LAE $(11.7 \pm 6.9 \mathrm{mg} / \mathrm{L})$ for 83 days; (4) Phase II, feeding of the reactor with lab-made sewage and commercial laundry wastewater containing LAS $(19.5 \pm 13.2)$ and LAE $(20.4 \pm$ 8.6) for 182 days, and (5) Phase III, feeding of the reactor with labmade sewage and commercial laundry wastewater containing LAS $(26.1 \pm 12.9 \mathrm{mg} / \mathrm{L}), \operatorname{LAE}(23.8 \pm 6.2 \mathrm{mg} / \mathrm{L})$ and co-substrate ethanol $(0.3 \mathrm{~mL} / \mathrm{L})$ for 175 days.

\subsubsection{Surfactant sample preparation of anaerobic fluidized bed reactor fed with laundry wastewater}

The influent and effluent samples from the anaerobic fluidized bed reactor feeding with laundry wastewater containing LAS and LAE were extracted using the SPE online system and analyzed by LC-MS/MS. Aliquots of $5 \mathrm{~mL}$ were collected and filtered through a $0.22 \mu \mathrm{m}$-pore-size membrane. The samples were frozen and stored in amber glass vials until analysis. It was not necessary to adjust the $\mathrm{pH}$ of the samples.

\section{Results and discussion}

Four major peaks were observed in the LC-MS/MS chromatogram for LAS (Fig. 3), and one peak was observed for LAE (Fig. 4). The minor peaks present in the LAS chromatogram are a mixture of isomers of each homologs present in the standard solution. The SRM transitions for homologs quantification LAS- $C_{10}$, LAS- $C_{11}$, LAS- $C_{12}$ and LAS- $C_{13}$ 


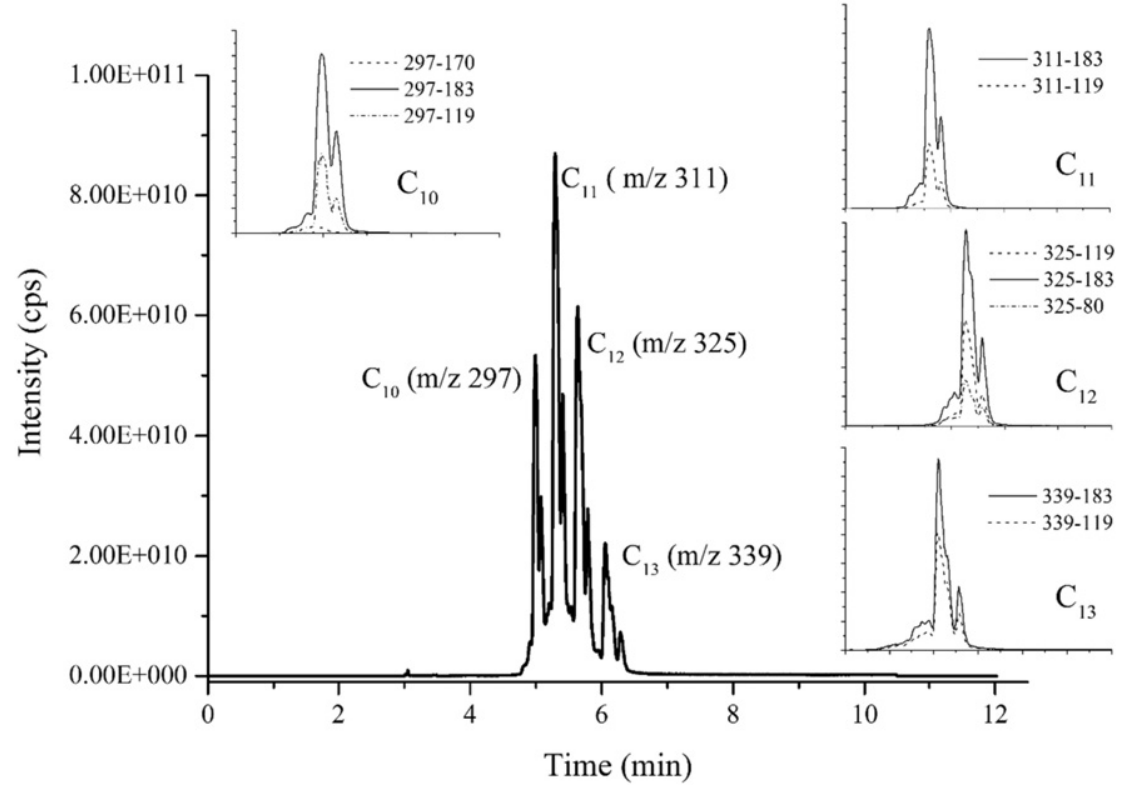

Fig. 3. LC-MS/MS chromatogram of linear alkylbenzene sulfonate (LAS); ESI( - ) and the respective SRM transitions $(m / z)$.

were 297-183, 311-183, 325-183 and 339-183, respectively, and an SRM transition of 645-89 was used for LAE quantification. Riu et al. (2001), González et al. (2007) and Rico-Rico et al. (2009) used LC-MS/ MS to determine LAS in marine sediment samples and effluents from sewage treatment plants and found SRM transitions similar to those found in this study.

\subsection{Validation}

The matrix may create interferences in the analysis that influence the signal and the concentrations of the analytes of interest, which results from the competition between the matrix components and target analytes (Trufelli et al., 2011). However, no interference, even in the retention times of the target analytes, was observed in this study. The LAS signal obtained in the lab-made sewage without surfactants had an intensity of $9.00 \mathrm{E}+09 \mathrm{cps}$, whereas the signal at the first point of the calibration curve had an intensity of $1.98 \mathrm{E}+10$. The LAE signal obtained

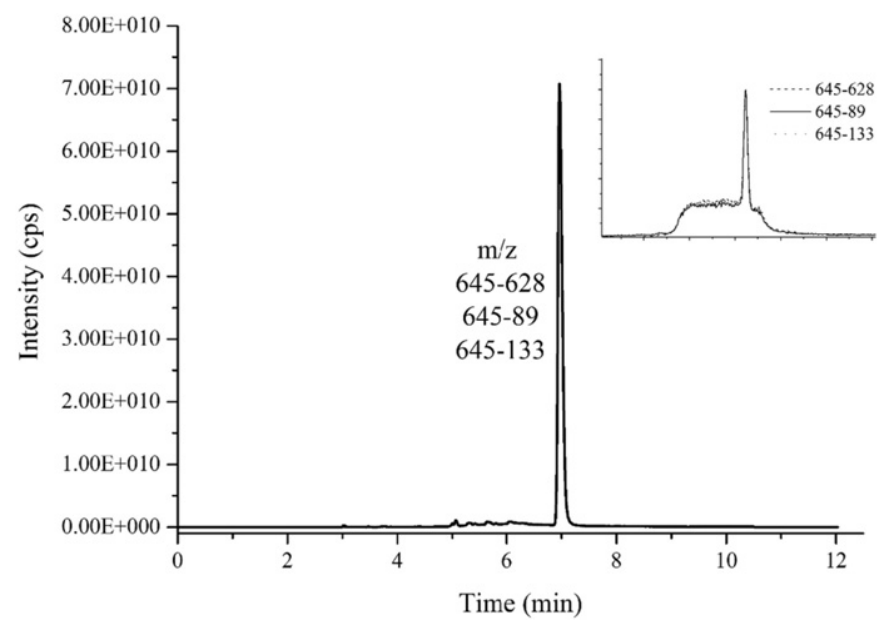

Fig. 4. LC-MS/MS chromatogram of linear alcohol ethoxylate (LAE); ESI(+) and the respective SRM transitions. from the lab-made sewage sample had an intensity of 5.97E $+08 \mathrm{cps}$, whereas the signal from the first point of the calibration curve was $1.02 \mathrm{E}+10$. Both samples were also compared with ultrapure water. In this way, both the matrix (lab-made sewage without surfactants) and ultrapure water did not influence the sample surfactants (data not shown).

According to Ribani et al. (2004), if the calibration curves obtained by spiking in lab-made sewage and ultra-pure water samples in the same concentration range presented identical slopes, it can be said that there is no interference of the matrix. Since such behavior was observed for this analytical method, the method is selective.

The mathematical relationship between the analytical signal or chromatogram areas and the mass or concentration of the target substance is known as the calibration curve (Ribani et al., 2004). The International Union of Pure and Applied Chemistry (IUPAC) specifies that the points of the calibration curve should be evenly spaced over the concentration range of interest and that this range should comprise $0 \%$ to $150 \%$ or $50 \%$ to $150 \%$ of the expected value, depending on which of these two options is most appropriate (Thompson et al., 2002). However, for surfactant analysis, these values become difficult to establish because of the extensive range of LAS and ethoxylate surfactant concentrations found in water bodies and sediments.

Braga and Varesche (2014) observed LAS concentrations in laundry wastewater between $12.2 \mathrm{mg} / \mathrm{L}$ to $1023.7 \mathrm{mg} / \mathrm{L}$. However, Gross et al. (2007) detected lower concentrations, between $4.7 \mathrm{mg} / \mathrm{L}$ and $15.6 \mathrm{mg} / \mathrm{L}$. For the nonionic surfactant alcohol ethoxylate (AE), even greater variations have been observed, from $0.9 \mu \mathrm{g} / \mathrm{L}$ in wastewater treatment systems using activated sludge processes (Morrall et al., 2006) to $141 \mathrm{mg} / \mathrm{L}$ in sludge of anaerobic reactors (Berna et al., 2007). González et al. (2007) studied the simultaneous extraction and analysis of surfactants in sediments from the coastal Catalonia region (Spain) by LC-MS with SPE extraction and verified concentrations of $307 \mu \mathrm{g} / \mathrm{L}$ to $1920 \mu \mathrm{g} / \mathrm{L}$ for LAS and $60 \mu \mathrm{g} / \mathrm{L}$ to $190 \mu \mathrm{g} / \mathrm{L}$ for the nonionic surfactant nonylphenol ethoxylate.

The calibration curve obtained for both surfactants was tested between $75 \mu \mathrm{g} / \mathrm{L}$ to $6000 \mu \mathrm{g} / \mathrm{L}$ to determine the best measurement range for both surfactants in a single chromatographic run. It was verified that the concentration range with better linearity was between $300 \mu \mathrm{g} / \mathrm{L}$ to $6000 \mu \mathrm{g} / \mathrm{L}$ for nine sample points between the minimum and maximum concentration, with linear behavior and no lack of fit. 
Repeatability was noted for both surfactants (from $300 \mu \mathrm{g} / \mathrm{L}$ to $6000 \mu \mathrm{g} / \mathrm{L}$ ), verifying the results of the linearity analysis and not showing any evidence of matrix interference (lab-made sewage) with the analytes. The RSD\%, MDL, MQL, linear concentration range and linear equation for each surfactant and their respective SRM transitions are shown in the Supplementary material. All the relative standard deviation (RSD\%) values obtained were $<20 \%$ (Supplementary material A1).

An MDL of $200 \mu \mathrm{g} / \mathrm{L}$ was found for the $\mathrm{C}_{13}$ homolog of LAS, and an MDL of $75 \mu \mathrm{g} / \mathrm{L}$ was found for the $C_{12}, C_{11}$ and $C_{10}$ homologs of LAS. LAE presented an MDL of $75 \mu \mathrm{g} / \mathrm{L}$. The MQL of LAS and LAE was $300 \mu \mathrm{g} / \mathrm{L}$, since it was possible to obtain a signal/noise ratio of 10:1 and an accuracy of $<20 \%$ for all analytes at this concentration level.

Lara-Martín et al. (2006) analyzed the extraction and simultaneous determination of linear alkylbenzene sulfonates (LAS), alkyl ethoxysulfates (AES) and alkyl sulfates (AS) in water and marine sediments using SPE (solid phase extraction) and subsequent LC-MS analysis. The authors obtained detection limits of $0.1 \mathrm{ng} / \mathrm{L}$ and $0.5 \mathrm{ng} / \mathrm{L}$ in aqueous samples using a calibration curve for the surfactants of $1 \mathrm{mg} / \mathrm{L}$ to $50 \mathrm{mg} / \mathrm{L}$. Similarly, González et al. (2007) determined detection limits of $50 \mathrm{ng} / \mathrm{L}$ for LAS and between $5 \mathrm{ng} / \mathrm{L}$ and $100 \mathrm{ng} / \mathrm{L}$ for nonionic surfactants (nonylphenol ethoxylate) in their analysis of marine sediment by LC-MS with SPE extraction.

In this study, the MQLs were higher than those found by González et al. (2007) for evaluation of the surfactant degradation efficiency using an anaerobic fluidized bed reactor. Additionally, this surfactant concentration allow the observation of whether inhibition had occurred by the microbial community in the reactor. Furthermore, the LAS and LAE concentrations detected in laundry wastewater were on the order of $\mathrm{mg} / \mathrm{L}$ (Braga and Varesche, 2014).

Di Corcia (1998) have reported detection limits for alcohol ethoxylate in the range of $0.6 \mu \mathrm{g} / \mathrm{L}$ in wastewater treatment systems. Cassani et al. (2004) studied the characterization of alcohol ethoxylate by LC-MS and observed a detection limit for derivatives of these nonionic surfactants of approximately $0.3 \mathrm{ng}$ to $0.5 \mathrm{ng}$ per ethoxy unit. These authors used a derivatization method with a sulfur trioxide complex ( $\mathrm{SO}_{3}-\mathrm{DMF}$ ) for each alcohol ethoxylate standard, increasing the signal of and sensitivity for this surfactant. In this study, the quantification limit for the alcohol ethoxylate was higher than that found by $\mathrm{Di}$ Corcia (1998) (382.9 $\mu \mathrm{g} / \mathrm{L})$. However, derivatization procedures were not used in the sample preparation, thus requiring less reagents and a shorter analysis time for the nonionic surfactants.

The solid phase extraction online technique combined with a liquid chromatography system (SPE online) represents a new LC-MS/MS method for the analysis of anionic and nonionic surfactants (LAS and LAE) in the same chromatographic run, which makes this study innovative compared to the others cited. Another advantage is that this analytical method does not use technical derivatization of the analytes, generating a fewer residual chemicals and requiring less reagent amounts and shorter analysis times for analysis of both surfactants present in the complex matrices of sewage and laundry wastewater.

Integrating the sample preparation with the chromatographic analysis resulted in a total analysis time of $22 \mathrm{~min}$ per chromatographic run. The required sample volume was $2 \mathrm{~mL}$ (to decrease errors in the dilution processes, when necessary), and only $100 \mu \mathrm{L}$ was injected for preconcentration and extraction.

This method had higher MDL and MQL values than those found in the literature for these surfactants measured by LC-MS/MS. The $100 \mu \mathrm{L}$ sample injection limited the analyte pre-concentration efficiency. In conventional SPE, an off-line sample of 0.5 to $2.0 \mathrm{~L}$ is processed, which increases the pre-concentration factor and leads to low MDL and MQL values. Although off-line SPE is a time-consuming sample preparation procedure, it uses large volumes of sample and organic solvent, which generates numerous chemical residues. Moreover, in this study, high surfactant concentrations (LAS and LAE) were used compared to those found in bodies of water to observe the removal of these compounds in a large-scale anaerobic fluidized bed reactor.
3.2. Application of the method to commercial laundry wastewater treatment

The anaerobic fluidized bed reactor of increased scale was operated for 480 days. The chemical oxygen demand (COD) of the influent was $626.5 \pm 24.5 \mathrm{mg} / \mathrm{L}, 445 \pm 12.2 \mathrm{mg} / \mathrm{L}, 588.6 \pm 8.9 \mathrm{mg} / \mathrm{L}$, and $852.4 \pm$ $30.1 \mathrm{mg} / \mathrm{L}$ in the adaptation phase, Phase I, Phase II and Phase III, respectively, which corresponded to organic loads of $633.1 \pm 324.6 \mathrm{mg}$ COD/$\mathrm{L} \cdot \mathrm{d}^{-1}, 449.7 \pm 66.9 \mathrm{mg} \mathrm{COD} / \mathrm{L} \cdot \mathrm{d}^{-1}, 586.2 \pm 159.3 \mathrm{mg} \mathrm{COD} / \mathrm{L} \cdot \mathrm{d}^{-1}$ and $861.3 \pm 276.8 \mathrm{mg} \mathrm{COD} / \mathrm{L} \cdot \mathrm{d}^{-1}$, respectively. The organic load resulted from the lab-made sewage and commercial laundry wastewater. The average organic matter removal efficiencies were $57.2 \pm 18.7 \%$, $76.4 \pm 7 \%, 48.4 \pm 12 \%, 62.4 \pm 22.4 \%$ for the adaptation phase, Phase I, Phase II and Phase III, respectively.

It was observed that organic matter removal was lower in the adaptation phase and Phase II: in these phases, bacterial colonization probably occurred in the support material (expanded clay) and was further adapted to the substrate (lab-made sewage). There was a surfactant load increase between Phase I $(8.7 \pm 5.2 \mathrm{mg} / \mathrm{L}$ of LAS and $11.7 \pm$ $6.9 \mathrm{mg} / \mathrm{L}$ of LAE $)$ and Phase II $(19.5 \pm 13.5 \mathrm{mg} / \mathrm{L}$ of LAS and $20.4 \pm$ $8.6 \mathrm{mg} / \mathrm{L}$ of LAE) that probably had a toxic effect on the biomass in Phase II (Fig. 5).

Braga et al. (2015) also observed a toxic effect caused by an increase in the LAS concentration in laundry wastewater in FRB (bench scale) with an HRT of $18 \mathrm{~h}$. These authors noted the decrease in the surfactant removal efficiency from $74.6 \pm 14.1 \%$ to $39.3 \pm 20.6 \%$ at LAS influent concentrations of $9.5 \pm 3.1 \mathrm{mg} / \mathrm{L}$ and $27.9 \pm 9.6 \mathrm{mg} / \mathrm{L}$, respectively. However, Motteran et al. (2014) observed no toxic effects when using the same reactor configuration with standard LAE influent concentrations of $4.7 \pm 2.2 \mathrm{mg} / \mathrm{L}$ to $107.4 \pm 47.3 \mathrm{mg} / \mathrm{L}$ without laundry wastewater. In this case, removal efficiencies between $97 \%$ and $99 \%$ were obtained. Thus, the toxic effects may be caused as much by the LAS concentration as by the other compounds in laundry wastewater.

The surfactant removal efficiencies for Phases I, II and III were $45.5 \pm 2.6 \%, 23 \pm 2.2 \%$ and $45.9 \pm 5.6 \%$ for LAS and $97.5 \pm 5.9 \%$, $87.7 \pm 19.7$ and $99.2 \pm 4.3 \%$ for LAE, respectively. The influent concentrations were $8.7 \pm 5.2 \mathrm{mg} / \mathrm{L}, 19.5 \pm 13.2 \mathrm{mg} / \mathrm{L}$ and $26.1 \pm 12.9 \mathrm{mg} / \mathrm{L}$ for LAS and $11.7 \pm 6.9 \mathrm{mg} / \mathrm{L}, 20.4 \pm 8.6 \mathrm{mg} / \mathrm{L}$ and $23.8 \pm 6.2 \mathrm{mg} / \mathrm{L}$ for $\mathrm{LAE}$, in the respective operational phases (Figs. 6 and 7). One-way analysis of variance (ANOVA, $\mathrm{P}<0.05$ ) was performed for the influent, effluent and efficiency samples for both LAS and LAE. ANOVA test showed that all the data were significantly different.

Higher LAE removal was observed when compared to LAS, probably due to the biodegradable characteristics of LAE once that LAS is derived from petroleum. Motteran et al. (2014) observed that LAE was biodegradable in a fluidized bed reactor under anaerobic conditions, with a removal of $98 \%$ from influent containing $97.9 \mathrm{mg} / \mathrm{L}$ of LAE. Another factor that may have influenced the difference in removal efficiency is the presence of toxic compounds in commercial laundry wastewater, which probably influenced LAS removal (Braga and Varesche, 2014). These authors detected compounds such as solvents, plasticizers, softeners, emulsifiers, pesticides, repellents, diluents, fragrances, preservatives and antioxidants using gas chromatography coupled with mass spectrometry (GC-MS). Solvents such as butanol (70.9\%) and ethanol (5.5\%) were the most commonly observed compounds in wastewater samples laundry, followed by compounds such as acetate (5.9\%) ethyl phthalate (5.0\%), nonylphenol ethoxylate (4.7\%) and the fragrance linalool (3.0\%).

The low removal values obtained in Phase II led to the addition of ethanol in the lab-made sewage. Macedo et al. (2015) evaluated the LAS degradation in a fluidized bed reactor and obtained high removal efficiencies for this surfactant using ethanol as a co-substrate. These authors observed an organic matter removal efficiency of $89.2 \pm 5.4 \%$ with ethanol in the FBR feeding. Thus, after the addition of $0.3 \mathrm{~mL} / \mathrm{L}$ of ethanol to the lab-made sewage containing laundry wastewater with $26.1 \pm 13 \mathrm{mg} / \mathrm{L}$ of LAS and $23.8 \pm 6.2 \mathrm{mg} / \mathrm{L}$ of LAE (Phase III), an 


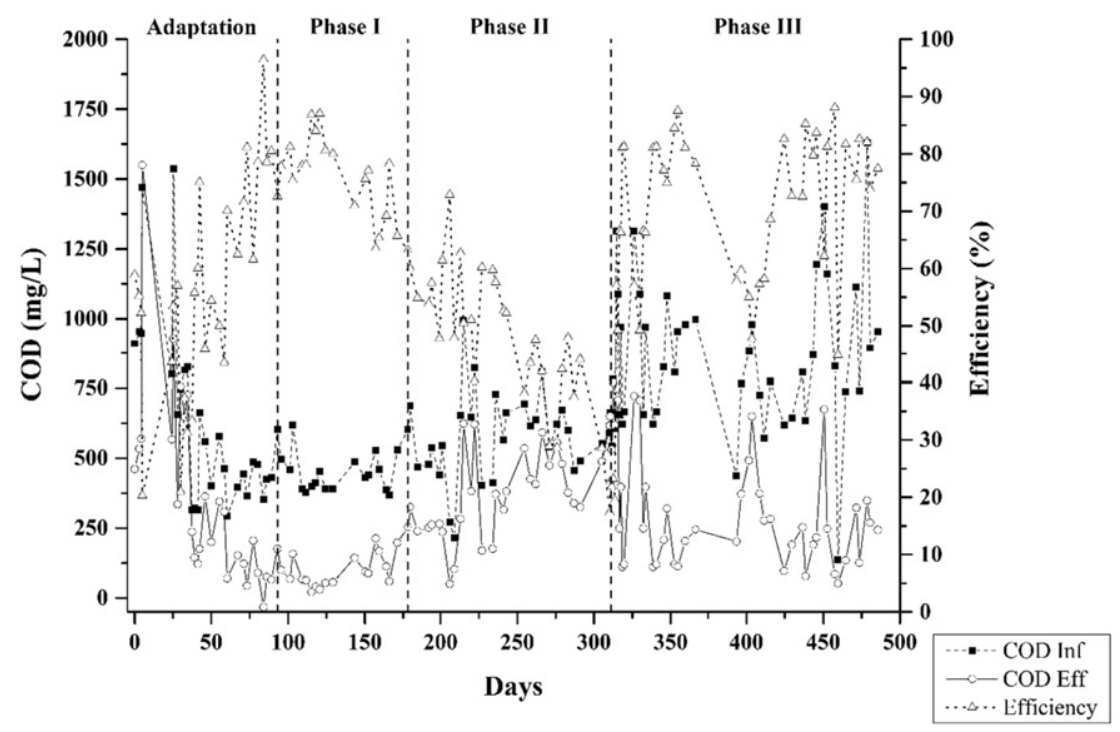

Fig. 5. Temporal variation of the average influent and effluent COD and efficiency removal of organic matter.

increase in the organic matter and surfactant removal efficiencies compared to those of Phase II was observed. Thus, ethanol as a co-substrate helped to remove LAS and LAE in this anaerobic reactor.

The average total alkalinity and $\mathrm{pH}$ in the influent and effluent of the anaerobic fluidized bed reactor denote stability in the presence of both surfactants in the commercial laundry wastewater. Most likely, under such conditions, a favorable environment was created for the development of microorganisms that were capable of degrading these toxic compounds, which consequently increased the organic matter, LAS and LAE removal efficiencies (Table 4).

Braga and Varesche (2014) observed a pH of $5.6 \pm 0.9$, with maximum and minimum values of 6.8 and 3.3, respectively, in the physicochemical characterization of commercial laundry wastewater. The total alkalinity observed by these authors was $25.9 \pm 20.2 \mathrm{mg} \mathrm{CaCO}_{3} /$ $\mathrm{L}$, with a maximum value of $82.1 \mathrm{mg} \mathrm{CaCO} / \mathrm{L}$. These values obtained by Braga and Varesche (2014) were much lower than those observed in this study, reasserting that the variety of surfactants and the influence of other compounds in the constitution of laundry wastewater makes this effluent a complex and unstable matrix for anaerobic biological treatment. Thus, a robust system is required to handle this high variation.

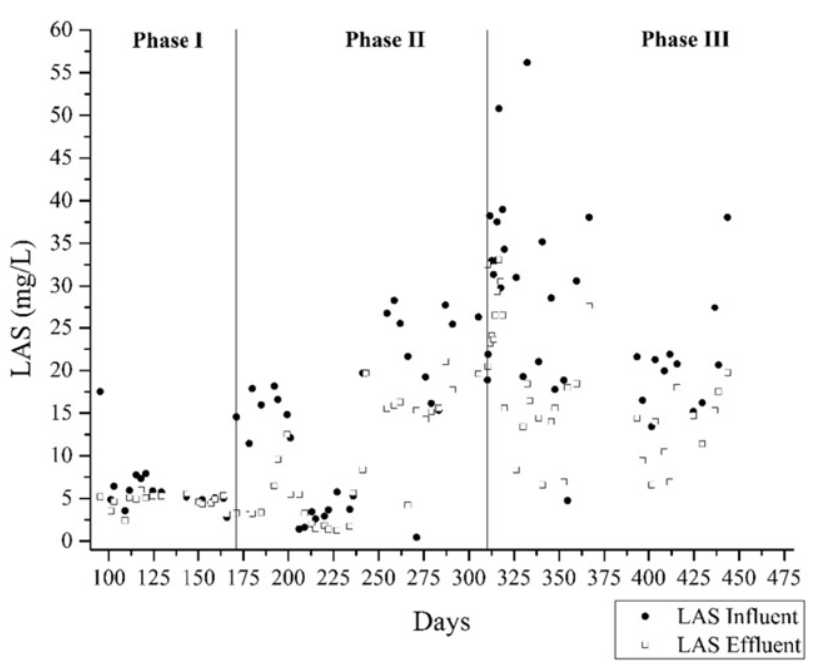

Fig. 6. Temporal variation of the average LAS concentration in the influent and effluent.

\subsection{Surfactant alkyl chain analysis}

During the operational phase, a change was observed in the removal efficiency of each LAS homolog $\left(\mathrm{C}_{10}, \mathrm{C}_{11}, \mathrm{C}_{12}\right.$ and $\left.\mathrm{C}_{13}\right)$ analyzed in the influent and effluent. For LAE, it was not possible to evaluate the homolog distribution from the SRM transition monitored, probably because of the higher removal efficiencies of the nonionic surfactant obtained in all operating phases.

The proportion of the $\mathrm{C}_{13}$ homolog of LAS in the Phase I influent $(0.7 \mathrm{mg} / \mathrm{L})$ decreased by $33 \%$ in the effluent $(0.2 \mathrm{mg} / \mathrm{L})$. The alkyl chain of this homolog may have been broken, decreasing the number of carbon atoms. This phenomenon can be evidenced by the increase in other shorter-chain homologs monitored in the effluent, mainly in the $\mathrm{C}_{12}$ homolog, whose proportion increased by $34.9 \%$ in the effluent ( $0.99 \mathrm{mg} / \mathrm{L})$ compared to its influent concentration $(0.73 \mathrm{mg} / \mathrm{L})$ (Fig. 8).

In Phase II, with the increase in the total surfactant concentration in the FBR $(19.5 \pm 13.5 \mathrm{mg} / \mathrm{L})$, a decrease in the removal efficiency of the $\mathrm{C}_{10}$ homolog (16.6\%) was observed from the influent $(4.0 \mathrm{mg} / \mathrm{L})$. However, a higher removal efficiency was observed for the $C_{13}(77.6 \%)$ and $\mathrm{C}_{12}(77.4 \%)$ homologs, with influent concentrations of $1.65 \mathrm{mg} / \mathrm{L}$ and $3.89 \mathrm{mg} / \mathrm{L}$, respectively, when compared to their respective effluent

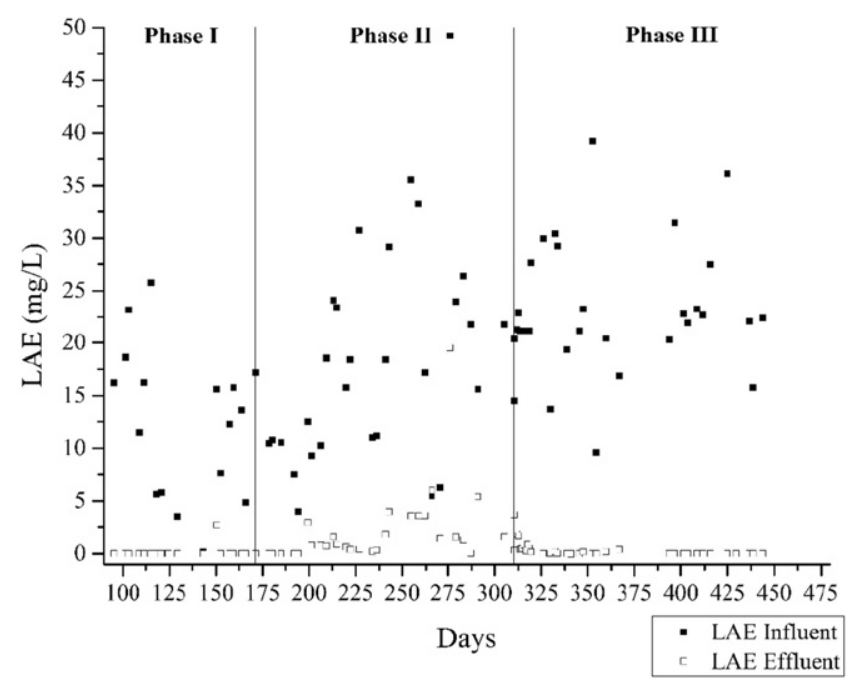

Fig. 7. Temporal variation of the average LAE concentration in the influent and effluent. 
Table 4

Total alkalinity and $\mathrm{pH}$ in the operational phases of the FBR.

\begin{tabular}{llllll}
\hline Phases & \multicolumn{2}{l}{$\begin{array}{l}\text { Total alkalinity } \\
(\mathrm{mg} \mathrm{CaCO} / \mathrm{L})\end{array}$} & & $\mathrm{pH}$ & \\
\cline { 2 - 3 } \cline { 5 - 6 } & Influent & Effluent & & Influent & Effluent \\
\hline Adaptation & $449.6 \pm 198.3$ & $542.2 \pm 230.9$ & & $6.9 \pm 0.3$ & $7.9 \pm 0.2$ \\
Phase I & $359.2 \pm 72.9$ & $454.5 \pm 51.9$ & & $7.3 \pm 0.2$ & $7.9 \pm 0.3$ \\
Phase II & $359.1 \pm 60.2$ & $462.1 \pm 76.7$ & & $7.3 \pm 0.2$ & $7.5 \pm 0.3$ \\
Phase III & $368 \pm 78.8$ & $442.2 \pm 88.5$ & & $7.1 \pm 0.1$ & $7.5 \pm 0.2$ \\
\hline
\end{tabular}

concentrations $(0.37 \mathrm{mg} / \mathrm{L}$ and $0.88 \mathrm{mg} / \mathrm{L})$. This result shows that there was breakage of the alkyl chains of these $C_{13}$ and $C_{12}$ homologs, which may have occurred through $\beta$-oxidation, thus freeing two carbon atoms. In this way, the carbon chains of the $C_{13}$ and $C_{12}$ homologs were reduced to $C_{11}$ and/or $C_{10}$ (Fig. 8).

According to Boll et al. (2002) the breakage of hydrocarbon chains requires molecular oxygen to be metabolized. Functional groups such as hydroxyl, carboxyl and carbonyl oxygen supply this need, facilitating the assimilation or processing of these complex molecules.

Some enzymes such as monooxygenases (flavin-containing hydroxylases or cytochrome P-450s) or dioxygenases are known for facilitating xenobiotic degradation (Sariaslani and Dalton, 1989). These enzymes in the metabolic pathways of alkanes incorporate hydroxyl groups into the aliphatic chain or the aromatic ring, which can generate alcohols that are then oxidized to organic acids such as succinate and fumarate (Heider et al., 1998). Cytochrome P-450 enzymes can add carbon atoms at the $\mathrm{C}-2$ position of alkanes under anaerobic conditions, and this carbon addition reaction represents a mechanism by which alkanes can be degraded without oxygen (So and Young, 1999).

In anaerobic environments, the addition of fumarate to the breakdown of recalcitrant compounds has been extensively studied. This co-substrate provides molecular oxygen for metabolism of these compounds via $\beta$-oxidation and tricarboxylic acid cycle routes (Boll et al., 2002). This feature has been documented by Lara-Martín et al. (2010), who proposed a LAS degradation pathway involving fumarate addition as a co-substrate. These authors observed a decrease in the LAS homolog series containing sulfophenyl carboxylic acids and by-products of this surfactant through degradation under anoxic conditions.

The process of alkyl chain breakage is driven by the attachment of an electron acceptor such as fumarate. However, in this study, mainly in Phase III, the electrons may have been provided by ethanol. In Phase III, there was an increase in the removal efficiency of all LAS homologs

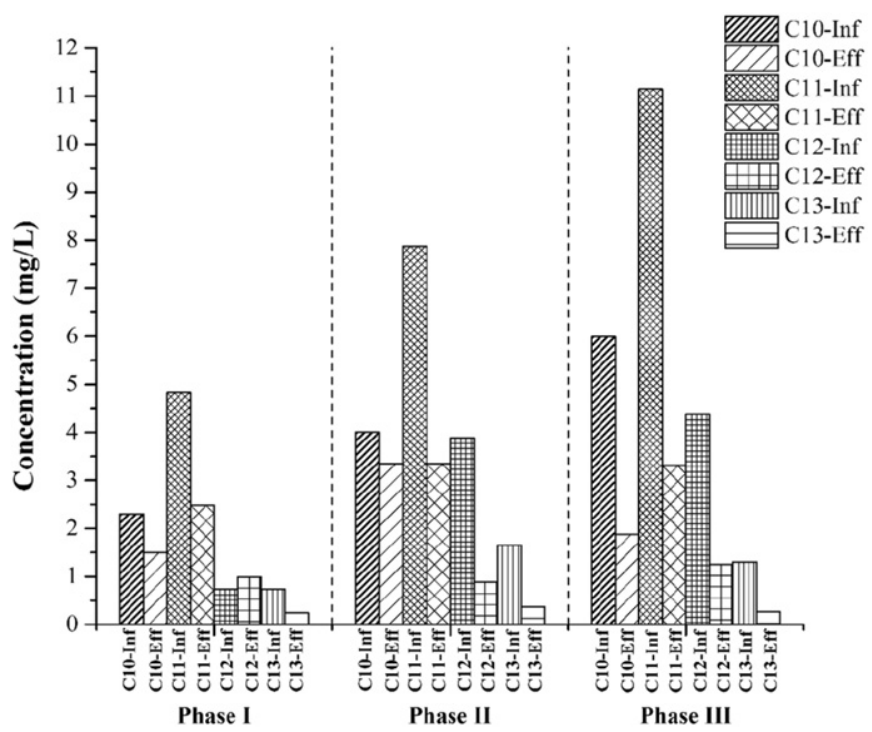

Fig. 8. Distribution of the LAS homologs $C_{10}, C_{11}, C_{12}$ and $C_{13}$ in the influent and effluent. compared with the other operational phases. The removal efficiencies were $68.7 \%, 70.3 \%, 71.3 \%$ and $80 \%$ for $C_{10}, C_{11}, C_{12}$ and $C_{13}$, respectively, with influent concentrations of $5.9 \mathrm{mg} / \mathrm{L}, 11.1 \mathrm{mg} / \mathrm{L}, 4.4 \mathrm{mg} / \mathrm{L}$ and $1.3 \mathrm{mg} / \mathrm{L}$ for the respective homologs. Thus, the LAS removal was higher in Phase III despite no significant increases in the homologs, indicating that alkyl chains of $<10$ carbon atoms break, which was not monitored in this study.

\section{Conclusion}

A column-switching SPE online method for analysis of the anionic surfactant linear alkylbenzene sulfonate (LAS) and the nonionic surfactant linear alcohol ethoxylate (LAE) in a single chromatographic run was developed and successfully applied. The configuration of the liquid chromatography tandem-mass spectrometry (LC-MS/MS) system used in this study is simple and conventional, and the use of an autosampler and column-switching system to facilitate the analysis of both surfactants makes this method faster and more efficient. The sample treatment consisted only of filtration, and derivatization processes were not required, making this method very economical. Compared to other chromatographic techniques for surfactant analysis, mainly for nonionic surfactants, smaller amounts of chemical residues were generated.

Sufficient selectivity was obtained for pre-concentrates of the LAS and LAE surfactants in the SPE column with an HLB phase, which proved to be effective for the two distinct categories of surfactants (anionic and nonionic) with different physicochemical characteristics. The method was validated in backflush mode, and the linearity, selectivity, precision and detectability were determined at relatively low concentrations on the order of $\mu \mathrm{g} / \mathrm{L}$ in samples from complex matrix. The method was considered robust after 480 days of reactor operation, as the concentrations of the calibration curve had not changed.

This method was efficiently applied in an anaerobic fluidized bed reactor of increased scale to study of commercial laundry wastewater containing anionic (LAS) and nonionic (LAE) surfactants, determining low concentrations of these compounds without interference from the matrix of the reactor effluent. The FBR operated under anaerobic conditions that afforded the metabolism of longer LAS homologs through the release of carbon units, which increased the number of homologs with shorter chains.

\section{Acknowledgments}

The authors would like to acknowledge FAPESP (Fundação de Amparo à Pesquisa do Estado de São Paulo) process no. 2013/19025-3 for the financial support.

\section{Appendix A. Supplementary data}

Supplementary data associated with this article can be found in the online version http://dx.doi.org/10.1016/j.scitotenv.2016.12.068. These data include the Google map of the most important areas described in this article.

\section{References}

APHA-AWWA-WEF, 2005. Standard Methods for the Examination of Water and Wastewater. 21st ed. (Washington, D.C.)

Berna, J.L., Cassani, G., Hager, C.-D., Rehman, N., López, I., Schowanek, D., Steber, J., Taeger, K., Wind, T., 2007. Anaerobic biodegradation of surfactants - scientific review. Tenside, Surfactants, Deterg. 44:312-347. http://dx.doi.org/10.3139/113.100351.

Boll, M., Fuchs, G. Heider, J., 2002. Anaerobic oxidation of aromatic compounds and hydrocarbons. Curr. Opin. Chem. Biol. 6:604-611. http://dx.doi.org/10.1016/S13675931(02)00375-7

Braga, J.K., Varesche, M.B.A., 2014. Commercial laundry water characterisation. Am. J. Anal. Chem. 2014:8-16. http://dx.doi.org/10.4236/ajac.2014.51002.

Braga, J.K., Motteran, F., Macedo, T.Z., Sakamoto, I.K., Delforno, T.P., Okada, D.Y., Silva, E.L., Varesche, M.B.A., 2015. Biodegradation of linear alkylbenzene sulfonate in commercial laundry wastewater by an anaerobic fluidized bed reactor. J. Environ. Sci. Health 
A Tox. Hazard. Subst. Environ. Eng. 50:946-957. http://dx.doi.org/10.1080/10934529. 2015.1030290

Brunner, P.H., Capri, S., Marcomini, A., Giger, W., 1988. Occurrence and behaviour of linear alkylbenzenesulphonates, nonylphenol, nonylphenol mono- and nonylphenol diethoxylates in sewage and sewage sludge treatment. Water Res. 22:1465-1472. http://dx.doi.org/10.1016/0043-1354(88)90157-1.

Cassani, G., Pratesi, C., Faccetti, L., Pravettoni, S., Nucci, G., Andriollo, N., Valtorta, L., Matheson, L., 2004. Characterization of alcohol ethoxylates as alcohol ethoxy sulfate derivatives by liquid chromatography-mass spectrometry. J. Surfactant Deterg. 7: 195-202. http://dx.doi.org/10.1007/s11743-004-0304-z.

Cassiano, N.M., Barreiro, J.C., Martins, L.R.R., Oliveira, R.V., Cass, Q.B., 2009. Validação em métodos cromatográficos para análises de pequenas moléculas em matrizes biológicas. Quim Nova 32:1021-1030. http://dx.doi.org/10.1590/S010040422009000400033.

Comber, S.D.W., Conrad, A.U., Höss, S., Webb, S., Marshall, S., 2006. Chronic toxicity of sediment-associated linear alkylbenzene sulphonates (LAS) to freshwater benthic organisms. Environ. Pollut. 144:661-668. http://dx.doi.org/10.1016/j.envpol.2005.12.049.

Cowan-Ellsberry, C., Belanger, S., Dorn, P., Dyer, S., McAvoy, D., Sanderson, H., Versteeg, D., Ferrer, D., Stanton, K., 2013. Environmental safety of the use of major surfactant classes in North America. Crit. Rev. Environ. Sci. Technol. 131121093229002. http://dx. doi.org/10.1080/10739149.2013.803777.

De Cooman, C., 2014. European committee of organic surfactants and their intermediates - Cesio 15. 10th World Surfactant Congress and Business Convention (www.cesiocongress.eu, Istanbul).

Di Corcia, A., 1998. Characterization of surfactants and their biointermediates by liquid chromatography-mass spectrometry. J. Chromatogr. A 794:165-185. http://dx.doi org/10.1016/S0021-9673(97)00678-X.

Dilallo, R., Albertson, O.E., 1961. Volatile acids by direct titration. J. Water Pollut. Control Fed. 33, 356-365.

Duarte, I.C.S., Oliveira, L.L., Saavedra, N.K.D., Fantinatti-Garboggini, F., Oliveira, V.M., Varesche, M.B.A., 2008. Evaluation of the microbial diversity in a horizontal-flow anaerobic immobilized biomass reactor treating linear alkylbenzene sulfonate. Biodegradation 19:375-385. http://dx.doi.org/10.1007/s10532-007-9143-5.

Dubey, S.T., Kravetz, L., Salanitro, J.P., 1995. Analysis of nonionic surfactants in bench-scale biotreater samples. J. Am. Oil Chem. Soc. 72:23-30. http://dx.doi.org/10.1007/ BF02635774.

Dyer, S.D., Sanderson, H., Waite, S.W., Van Compernolle, R., Price, B., Nielsen, A.M., Evans, A., Decarvalho, A.J., Hooton, D.J., Sherren, A.J., 2006. Assessment of alcohol ethoxylate surfactants and fatty alcohols mixtures in river sediments and prospective risk assessment. Environ. Monit. Assess. 120:45-63. http://dx.doi.org/10.1007/s10661005-9048-X.

Evans, K.A., Dubey, S.T., Kravetz, L., Evetts, S.W., Dzidic, I., Dooyema, C.C., 1997. Quantitation of alcohol ethoxylate surfactants in environmental samples by electrospray mass spectrometry. J. Am. Oil Chem. Soc. 74:765-773. http://dx.doi.org/10.1007/s11746997-0216-8.

González, S., Petrovic, M., Barceló, D., 2007. Removal of a broad range of surfactants from municipal wastewater - comparison between membrane bioreactor and conventional activated sludge treatment. Chemosphere 67:335-343. http://dx.doi.org/10.1016/j. chemosphere.2006.09.056.

Gross, A., Shmueli, O., Ronen, Z., Raveh, E., 2007. Recycled vertical flow constructed wetland (RVFCW) - a novel method of recycling greywater for irrigation in small communities and households. Chemosphere 66:916-923. http://dx.doi.org/10.1016/j. chemosphere.2006.06.006.

Heider, J., Spormann, A.M., Beller, H.R., Widdel, F., 1998. Anaerobic bacterial metabolism of hydrocarbons. FEMS Microbiol. Rev. 22:459-473. http://dx.doi.org/10.1016/ S0168-6445(98)00025-4.

HERA, 2009. Human \& Environmental Risk Assessment on Ingredients of European Household Cleaning Products. pp. 1-81.

ICH, 2005. International conference on harmonisation of technical requirements for registration of pharmaceuticals for human use, validation of analytical procedures: text and methodology Q2(R1). Current Step 4 Version (Rockville).

Lara-Martín, P.A., Gómez-Parra, A., González-Mazo, E., 2006. Simultaneous extraction and determination of anionic surfactants in waters and sediments. J. Chromatogr. A 1114: 205-210. http://dx.doi.org/10.1016/j.chroma.2006.03.014.

Lara-Martín, P.A., Gómez-Parra, A., Sanz, J.L., González-Mazo, E., 2010. Anaerobic degradation pathway of linear alkylbenzene sulfonates (LAS) in sulfate-reducing marine sediments. Environ. Sci. Technol. 44:1670-1676. http://dx.doi.org/10.1021/es9032887.

Lara-Martín, P.A., González-Mazo, E., Brownawell, B.J., 2012. Environmental analysis of alcohol ethoxylates and nonylphenol ethoxylate metabolites by ultra-performance liquid chromatography-tandem mass spectrometry. Anal. Bioanal. Chem. 402: 2359-2368. http://dx.doi.org/10.1007/s00216-011-5449-6.

Larson, R.J., Rothgeb, T.M., Shimp, R.J., Ward, T.E., ventullo, R.M., 1995. Kinetics and practical significance of biodegradation linear alkylbenzene sulfonate (LAS) in the environment. CLER Rev. 1, 4-19.

Lima Gomes, P.C.F., Tomita, I.N., Santos-Neto, Á.J., Zaiat, M., 2015. Rapid determination of 12 antibiotics and caffeine in sewage and bioreactor effluent by online columnswitching liquid chromatography/tandem mass spectrometry. Anal. Bioanal. Chem. 407:8787-8801. http://dx.doi.org/10.1007/s00216-015-9038-y.

Macedo, T.Z., Okada, D.Y., Delforno, T.P., Braga, J.K., Silva, E.L., Varesche, M.B.A., 2015. The comparative advantages of ethanol and sucrose as co-substrates in the degradation of an anionic surfactant: microbial community selection. Bioprocess Biosyst. Eng. http:// dx.doi.org/10.1007/s00449-015-1424-5.

Mayer, P., Vaes, W.H.J., Wijnker, F., Legierse, K.C.H.M., Kraaij, R.H., Tolls, J., Hermens, J.L.M., 2000. Sensing dissolved sediment porewater concentrations of persistent and bioaccumulative pollutants using disposable solid-phase microextraction fibers. Environ. Sci. Technol. 34:5177-5183. http://dx.doi.org/10.1021/es001179g.

Morrall, S.W., Dunphy, J.C., Cano, M.L., Evans, A., McAvoy, D.C., Price, B.P., Eckhoff, W.S 2006. Removal and environmental exposure of alcohol ethoxylates in US sewage treatment. Ecotoxicol. Environ. Saf. 64:3-13. http://dx.doi.org/10.1016/j.ecoenv. 2005.07.014.

Motteran, F., Braga, J.K., Sakamoto, I.K., Silva, E.L., Varesche, M.B.A., 2014. Degradation of high concentrations of nonionic surfactant (linear alcohol ethoxylate) in an anaerobic fluidized bed reactor. Sci. Total Environ. 481:121-128. http://dx.doi.org/10.1016/j. scitotenv.2014.02.024.

Pan, J., Zhang, C., Zhang, Z., Li, G., 2014. Review of online coupling of sample preparation techniques with liquid chromatography. Anal. Chim. Acta 815:1-15. http://dx.doi. org/10.1016/j.aca.2014.01.017.

Prats, D., Ruiz, F., Vázquez, B., Rodriguez-Pastor, M. 1997. Removal of anionic and nonionic surfactants in a wastewater treatment plant with anaerobic digestion. A comparative study. Water Res. 31:1925-1930. http://dx.doi.org/10.1016/S00431354(97)00040-7.

Ribani, M., Bottoli, C.B.G., Collins, C.H., Jardim, I.C.S.F., Melo, L.F.C., 2004. Validação em métodos cromatográficos e eletroforéticos. Quim Nova 27:771-780. http://dx.doi. org/10.1590/S0100-40422004000500017.

Rico-Rico, A., Droge, S.T.J., Widmer, D., Hermens, J.L.M., 2009. Freely dissolved concentrations of anionic surfactants in seawater solutions: optimization of the non-depletive solid-phase microextraction method and application to linear alkylbenzene sulfonates. J. Chromatogr. A 1216:2996-3002. http://dx.doi.org/10.1016/j.chroma.2009. 01.090 .

Ripley, L.E., Boyle, W.C., Converse, J.C., 1986. Improved alkalimetric monitoring for anaerobic digestion of high-strength wastes. J. Water Pollut. Control Fed. 58, 406-411.

Riu, J., Martínez, E.., Barceló, D., Ginebreda, A., Tirapu, L., 2001. LC-MS determination of linear alkylbenzene sulfonates and their carboxylic degradation products in influent and effluent water samples and sludges from sewage-treatment plants. Fresenius J. Anal Chem. 371:448-455. http://dx.doi.org/10.1007/s002160101052.

Sariaslani, F.S., Dalton, H., 1989. Microbial enzymes for oxidation of organic molecules. Crit. Rev. Biotechnol. 9:171-257. http://dx.doi.org/10.3109/07388558909036736.

So, C.M., Young, L.Y., 1999. Initial reactions in anaerobic alkane degradation by a sulfate reducer, strain AK-01. Appl. Environ. Microbiol. 65, 5532-5540.

ter Laak, T.L., Agbo, S.O., Barendregt, A., Hermens, J.L.M., 2006. Freely dissolved concentrations of PAHs in soil pore water: measurements via solid-phase extraction and consequences for soil tests. Environ. Sci. Technol. 40:1307-1313. http://dx.doi.org/10. 1021/es0514803.

Thiele, B., 2005. Surfactants. In: Nollet, L.M.L. (Ed.), Chromatographic Analysis of the Environment. CRC Press:pp. 1173-1198 http://dx.doi.org/10.1201/9781420027983. ch30.

Thompson, M., Ellison, S.L., Wood, R., 2002. Harmonized Guidelines for Single-laboratory Validation of Methods of Analysis (IUPAC Technical Report). 74 pp. 835-855.

Tolls, J., Haller, M., Sijm, D.T.H.M., 1999. Extraction and isolation of linear alcohol ethoxylates from fish. 839, 109-117.

Trufelli, H., Palma, P., Famiglini, G., Cappiello, A., 2011. An overview of matrix effects in liquid chromatography-mass spectrometry. Mass Spectrom. Rev. 30:491-509. http://dx. doi.org/10.1002/mas.20298.

Ying, G.-G.G., 2006. Fate, behavior and effects of surfactants and their degradation products in the environment. Environ. Int. 32:417-431. http://dx.doi.org/10.1016/j envint.2005.07.004. 